\title{
Keeping the state accountable: is aid no better than oil? ${ }^{1}$
}

By

Ole Therkildsen

Aid may influence accountability relations in recipient countries in various direct and indirect ways. One set of mechanisms are the ways in which aid and aid donors affect taxation and related processes within recipient countries - the amount of tax raised, the choice among different types of taxes, collection methods, budgeting, and public spending patterns. The purpose of this article is to evaluate what we know about these issues, with special reference to aid-dependent Sub-Saharan African countries.

The aid-taxation nexus is relatively neglected in the debate about how donors may influence accountability relations within aid dependent countries. Much attention is, for example, devoted to the effects of the involvement of donors in activities that directly aim to strengthen public administrative accountability through improvements in organisational arrangements, budgeting, accounting, and reporting procedures. The debate also focuses on political accountability. Donors try, for instance, to promote democratisation through support for or conditionalities about multiparty elections, strengthening of non-governmental organisations, and funding of citizens' awareness campaigns. Donors have placed more emphasis on these issues during the 1990s, and there is a lively debate about their impact (Goldsmith, 2001). Some of the indirect channels through which donors affect accountability processes in recipient countries are also much debated: for example, the influence of aid on fragmentation of public institutions and budgeting processes; on corruption; and on prioritising accountability to donors rather than to domestic political actors (Therkildsen, 2001a).

That aid, and donors, may affect taxation - and through this may influence accountability relations - has only recently started to receive attention. Moore (1998,

\footnotetext{
${ }^{1}$ This paper was written in connection with the research programme 'Taxation, Aid and Democracy' funded by the Research Council of Norway and by Danida.
} 
2001) has developed an idea that is examined in this article: that aid, much like oil income, influences state-society relations in specific, harmful ways. Inspired by rentier state theories, ${ }^{2}$ the basic argument is that when states gain substantial incomes from external sources, such as oil, minerals or foreign assistance, they do not need to levy domestic taxes and therefore become less accountable to the societies they govern aid=oil). The other proposition examined here is that donors, through their influence on tax policies and administration - in particular in setting revenue targets have considerable influence on tax collection methods and budgeting in ways that may weaken accountability. The aid=oil argument is assessed using the results of Ross' (2001) great efforts empirically to test the impact of oil incomes on accountability relations using rentier state theories. The link from donors to tax collection methods and budgeting is illustrated by findings from an ongoing research programme on taxation, aid and democracy (Fjeldstad et. al., 2000).

I conclude that incomes from oil and aid share some common features that justify the use of rentier state theories to assess possible aid-accountability linkages. On the other hand, there are also differences: aid, and donors, may influence accountability relations in ways that are not captured by such theories. Conclusions are drawn in the final section.

\section{Aid donors, state incomes and state expenditures}

Incomes from oil and aid share some common features. They are paid by foreign actors; they are often substantial and accrue directly to the state; and only few people in the recipient government are involved in generating them, while many are involved in using and distributing them(Beblawi, 1997, 51). Moore's (1998) conceptualisation of aid as 'unearned income' fits. These common features justify the use of rentier state theories to explore how aid may influence governance relations. However, there are also differences between oil and aid income. The use of oil income is typically controlled by oil exporting governments themselves. In contrast, aid funds are never completely controlled by the recipient governments, not even general budget support or other less conditional types of aid. Donors influence taxation practices of recipient

\footnotetext{
${ }^{2}$ Reviewed, for example, by Cooley (1999) and Ross (1999, 2001).
} 
governments in a number of ways that have no parallel in oil economies. Donor influence ranges from providing technical advice and funds with few strings attached to conditional demands for specific policies on tax or other issues, sometimes tied to signals about withdrawal of funding in cases of non-compliance.

Aid is provided through various modalities depending on its motivation (military, political, commercial, cultural or developmental) and on changing ideas about aid policy. In the 1990s, there has been an increasing focus on institutions, governance, civil society organisations and poverty in addition to the continuing focus on macroeconomic policies. The composition of aid flows has changed correspondingly, with a growing emphasis on untied balance-of-payment support and debt relief - and less on project aid (World Bank, 2000, chapter 8). Next, donors influence recipient tax policies. For years, the IMF and the World Bank in particular have pushed for revenue enhancement (higher ratios of government revenue to GDP); broadening the tax base (typically through the introduction of Value Added Tax, reduction of exemptions, etc); and reducing and simplifying tax rates to increase compliance and diminish economic distortions. These prescriptions tend to be "one size fits all" despite wide differences in existing tax systems across countries. In addition, donors have become increasingly involved in tax administration and tax collection methods. Most prominently, they have actively supported the establishment of Revenue Authorities as executive agencies. These have especially spread in English speaking countries during the 1990s (Gloppner and Rakner in this Bulletin). More generally, donors have provided assistance to strengthen tax administration and accountability, to improve taxpayer compliance and to diminish corruption. The focus has been on efficiency. Little or no efforts have been made to strengthen taxpayers' voice (Barbone et al., 1999, table 2). Finally, donors have taken an active interest in how state incomes are spent - not only aid funds, but also domestically generated revenues. The focus on the expenditure side is evident in the structural adjustment programmes that started in the 1980s. It is also reflected in donors' recent concern with poverty reduction strategies. Local government taxation is the only major area of revenue generation - measured in terms of the number of people in contact with tax authorities, not in the amount of funds actually collected - in which donors so far have been relatively inactive. 
Over the last couple of decades, there have been major changes in this taxation-aiddonor nexus. The per capita size of donor funds to Sub-Saharan Africa peaked in 1990 and since declined by 60 percent. On the other hand, donor involvement in tax policies and administration - as well as in expenditure policies - seems to have increased steadily in many countries. There are, however, wide differences in donor involvement across countries. The taxation-aid-donor nexus is a moving object of study, whose influence on accountability is complex and multi-directional.

\section{Testable propositions based on rentier state theories}

To the extent that aid is relatively untied, it may affect state-society relations in ways similar to oil incomes. According to rentier state theories, which were developed by scholars of the Middle East to explain the prominence of authoritarian regimes in this region, oil incomes strongly influence political bargaining processes - or the lack of them- between state and society.

Ross (2001) has made the most ambitious attempts so far to test of the hypothesis that oil hinders democracy. ${ }^{3}$ Scepticism about this kind of analysis is justified because it depends on the quantification of complex political and social processes that vary widely across countries. Its strength are the variety of cases covered and the testing of specific causal mechanisms linking state incomes from oil and political outcomes. If the results are treated as suggestive rather than conclusive, as Ross himself

\footnotetext{
${ }^{3}$ He uses regression analyses on pooled time-series cross-national data from 113 states between 1971 and 1997. These include a variety of oil and non-oil exporters, rich and poor countries, and countries from OECD, Latin America, Africa, Asia and the Middle East. 'Regime' is the dependent variable - a composite of indicators of autocracy and democracy. It includes measures of the way chief executives are recruited; whether they are constrained by, and accountable to, other actors; the existence of competitive elections, and so on (p.358). Among the independent controlling variables are income, religion (Islam), region and regime type in the prior five-year period.
} 
recommends, his work also contributes to a better empirically based understanding of the accountability effects of aid and donors.

\section{The effect of unearned income}

Ross's central finding is that oil exports are strongly associated with authoritarian rule and this effect is not limited to the Middle East. Moreover, oil wealth matters not only when it comprises very high proportions of GDP: "barrel for barrel, oil harms democracy more in oil-poor than in oil-rich ones" (Ross, 2001, 343). The effects occur over relatively short periods. ${ }^{4}$ This suggests that even modest levels of aid to poor countries may affect accountability relations; that the effects may occur in the short run; and that the timing of aid in relation to the recipient country's social and political context is very important for the influences that aid is likely to have on statesociety relations.

What are the causal mechanisms that may explain such antidemocratic properties of oil? Ross identifies several testable causal mechanisms derived from rentier state and other theories.

\section{"Taxation effects"}

According to Ross, they occur because states receiving "sufficient incomes" from the sale of oil are likely to tax their populations less. In turn, the public will be less likely to demand accountability from - and representation in - their government (p. 332). This is a core proposition of rentier state theories. Things get complicated here. Are states satisfiers or maximisers of incomes? Ross argues the former; other researchers disagree. Devarajan et. al. (1999), for example, find that aid has little impact on aggregate levels of taxation. Moore (1998) notes the same.

However, Ross claims support for the taxation effect on the basis of the finding that the proportion of state revenues derived from personal and income taxes is strongly and positively associated with more accountable government. This is really a test of the influence of the composition of state revenues on regime type - rather than their

\footnotetext{
${ }^{4}$ On the other hand, large oil discoveries in rich European states like Britain,
} Denmark and Norway do not appear to have significant anti-democratic effects. 
size. Furthermore, the direction of causality may run the opposite way: regime type may influence the composition of revenue. Ross dismisses this, possibility arguing that "more democratic governments should be less disposed to fund themselves through personal and corporate taxes, given their unpopularity" (p.348-9). This seems to contradict his own finding and is factually problematic. On the one hand, personal income tax and the emergence of democratic representation seem closely linked in Western countries leading to growing reliance on direct taxation (with variations across countries) over the last hundred years (Tanzi and Schuknecht, 2000, table III.2). On the other hand, in Latin American, where democratisation and political freedoms have progressed, personal income taxation is low and falling. States here seem to have a weak leverage over their economic elites (DiJohn and Putzel, 2000, 29).

This implies that the "taxation effect" of aid funds may be less straightforward than claimed by rentier state theories. Even if aid may make states more independent of their societies in revenue terms, state actors are not shielded from the social bases of support that help to keep them in power. Conceivably, aid could, in some contexts, help to strengthen social groups demanding more taxation for various purposes as well as the state's capacity to enforce such taxation. In other contexts, aid may have the opposite effects. Therefore the extent to which aid may influence tax efforts (political and administrative), choices of tax instruments (hence revenue composition), and tax incidence (and hence who will carry the tax burden) is an empirical question best assessed in a specific context.

\section{Expenditure effects}

Rentier state theories focus not only on how state incomes are obtained, but also on how they are spent. Ross identifies three causal mechanisms. "Spending effects" arise because incomes from oil may lead to greater spending on patronage, which in turn reduces demands for democratisation. A "group formation effect" occurs when the state uses its incomes to prevent formation of independent social groups that may demand political rights. Finally, a "repression effect" occurs when incomes from oil allow recipient states to spend more on internal security, and so block democratic aspirations. 
Ross finds statistical support for all three effects, but the limitations of his approach are obvious. Thus, he measures the "spending effect" by government consumption as percentage of GDP. This consumption includes all current spending for purchases of goods and services including wages and salaries. The "group formation" effect is captured by the share of GDP accounted for by government activities, while the "repression effect" is measured by military spending. These are very crude and simplified indicators. Their magnitudes tell little about the extent to which political support is purchased through patronage, independent groups are suppressed through expanding government activities, or military spending is actually used for internal oppression.

Nevertheless, Ross is right in pointing out that the way states spend incomes may have implications for the political bargaining processes. The assumption in rentier state theories is that abundant state funds are used strategically for political purposes and that such spending discourages opposition groups from mobilising. This is an interesting proposition, but it is questionable whether spending only has the intended de-mobilising effects.

With respect to aid, there are clear cases of it being given by donors and used by recipient governments to avert political demands for representation and accountability, especially during the Cold War period. Such cases may re-emerge in the new war on terrorism. Yet, at present, donors typically try to limit military spending, and to encourage the funding of social services and non-governmental organisations. This, as well as domestic pressures, have helped to change recipient government expenditures in some countries (Therkildsen, 2001a). How this may affect political mobilisation is unclear. The increased funding of social services may promote tax compliance, although the causal linkages are complex (Therkildsen, 2001b). It may also increase demands for extending such service to other groups. We lack understanding of how specific spending patterns affect the political bargaining processes with respect to representation and demands for accountability.

\section{Societal factors}

Modernisation theory holds that democratisation is influenced by changes in occupational specialisation, urbanisation and levels of education, which in turn are 
caused by economic development. Ross uses such societal factors to explain variations in accountability relations across countries and claims some support for their significance - although the evidence is not very convincing, as he admits (p. 354, footnote 70). His choice of modernisation theories is probably motivated by the need to find quantifiable variables for the regression analyses. To find such variables it is, however, more relevant to focus on how taxation may affect societal groups and political bargaining.

One line of thinking emphasises the importance of owners or controllers of mobile capital. It is influenced by European experiences (summarised by Moore, 1998, 2001). Here, representative government eme rged from political struggles between rulers and private owners of capital about taxation in exchange for representation and influence on spending. Negotiation was to the advantage of both parties as taxes became more predictable and revenues more stable. Corporate representation of owners of capital was necessary for such bargaining to be effective. But this process did not take root everywhere. In addition, cultural context and economic structure played an important role. The process was most pronounced where capital was mobile (i.e. in the form of financial and trading assets). Here the mutual advantages of co-operation were greatest.

Another line of thinking focuses on the political importance of certain types of immobile capital. It is influenced by research in poor and developmental states. The argument is that the autonomy of a state - and hence its capacity to tax - varies across economic sectors and is particularly influenced by the leading export sectors (Shaffer, 1995). State autonomy is especially low in relation to sectors characterised by both (a) high barriers to entry and exit and a limited ability to cope with international market fluctuations and (b) domination by a few large firms able to overcome collective action problems. Mining and plantation-based export activities dominated by multinational corporations are examples of such inflexible sectors, as Shaffer calls them. These sectors, including their organised labour interests, are difficult to govern due both to their capacity to press demands for assistance on the state, and to their vulnerability to international market swings. 
Over the years, aid has been used to both strengthen and weaken mobile and immobile capital as donors often actively support economic interest groups and their capacity to access and influence government policies on taxation and tax administration (Rakner, 2001). This support may have both short and long term influences on tax based accountability relations. To these various economic relations should be added social relations of power which may have reinforcing, neutralising or countervailing effects on economy-influenced state-society relations (Eriksen, 2001). Knowledge about how aid influences societal political demands is still limited.

\section{Other propositions}

From a taxation point of view, the main difference between oil and aid income is that donors are increasingly directly involved in recipient country tax policy making and tax administration - even if some aid (like oil) is given with few strings attached and requires little effort by recipient governments vis-à-vis its taxpayers. This donor involvement may have significant but unintended influences on state accountability. Donor involvement in revenue target setting is a particularly illustrative case of this. As the following analyses shows, it can have important implications for tax collection methods and hence for taxpayer rights as well as for administrative accountability. Obviously, such effects are not considered in the rentier state theories and the empirical tests of the theories that were summarised above.

\section{Revenue targets and taxpayer rights}

Fjeldstad (2001) has shown how coercion in local government tax collection may be an unintended result of donor demands for matching funds from local authorities receiving aid. We have less evidence on the ways in which accountability is affected by donor demands for higher central government revenue. This may result in distortions of formal procedures for tax collection and misuse of power as effective protection of taxpayer rights is weak (Luoga, this volume).

In Tanzania and Uganda, as elsewhere, a reduction of the budget deficit is an important concern and it is a central component of the Washington consensus prescriptions. Increasing revenues is one way to address a budget deficit. Targets for 
the ratio of revenue to GDP are therefore often written into agreements with the IMF. Such targets are taken seriously because an IMF-supported programme is, in practice, a condition for receiving programme aid from other donors as well (Bulir and Hamann, 2001, 6).

For Tanzania, a target of a one-percentage point of GDP increase from 1999 was regarded as "conservative" by the World Bank $(1999,6)$, despite very modest improvements in aggregate revenue collection before that. This target has not been achieved. For Uga nda, the annual targets were two percentage point increases in revenue of GDP in the early 1990s, one in the mid-1990s, and $0.5 \%$ at the end of the decade. This latter figure remains the long-term goal. Despite the se reductions over time, these targets have not been met either. There is no indication that they were discussed or sanctioned by Parliament before agreement with the multilateral donors.

Interviews with staff in the organisations involved, and with close observers outside them, give the clear impression that revenue target setting is more of an art than a science. Moreover, technical feasibility is just one criterion for setting targets. Other motivations are to put pressure on the tax administration to do better, and to justify donor support for tax administration. Such ambitious targets influence tax collection efforts and methods. To meet targets, tax collectors tend to focus on relatively large and profitable taxpayers operating in the formal economy. The pressure amplifies the "arbitrariness" that characterises tax administration in Tanzania and Uganda (Reinikka and Svenson, 1999, 28; see also Anena and Gariyo, 2000; Luoga, 2001 and this volume). Among the signs are the frequent and drawn out audits; the limited time given to taxpayers to respond to inquiries; the arbitrary disallowance of expenses; bribing; delays in tax refunding; early resort to distraint and attachment measures; and poor or non-existent adjudication of tax disputes.

Over-ambitious, donor-influenced, revenue targets do not cause such tax administration problems, but make them worse and point to fundamental issues of citizenship as Luoga points out. For increased emphasis on revenue targets highlights 
the lack of adequate protection of taxpayer rights; uncertainty and ambiguities of tax laws and regulations; and the serious problems with appeal mechanisms. ${ }^{5}$

\section{Revenue targets, cash budgets and accountability}

Moore (1998, 106-109) has pointed out how donor funding may cause fragmentation of already weakly institutionalised budgeting and auditing. This further undermines budget-based accountability mechanisms. The sectoral investment programmes, in which donors pool their funds to support sector-wide activities, is therefore a step in the right direction. On the other hand, the cash budgeting arrangements introduced in many African countries in the 1990s may create new accountability problems related to budgeting and revenues.

Cash budgeting is an institutional innovation that aims to reduce excessive fiscal deficits. Specific arrangements vary across countries but two features are common. One is that the main expenditure-control mechanism is the monitoring of cash disbursements rather than line ministries' expenditure commitments. The other is that actual cash disbursements depend on the revenues and aid incomes actually obtained. No public money is to be disbursed without funds in hand. Uganda was the first African country to adopt this arrangement in 1992. Tanzania followed some years later, as did several other countries. Experiences have shown that fiscal discipline did improve because the cash budget arrangement strengthens the control of ministries of finance over line ministries' expenditures (Stasavage and Moyo, 2000). On the other

\footnotetext{
${ }^{5}$ Taxpayer rights problems are not confined to central government taxation. A sample survey of central and local government prisons in Uganda shows that the likelihood of prison detention is much higher for non-payment of the Graduated Personal Tax (GPT is collected by and accruing to local authorities) than for non-payment or evasion of central government taxes. The arbitrariness of taxation is exacerbated by the fact that the GPT is small, and only paid by a fraction of the liable population, while taxes due to central government are generally much higher, and believed to be frequently evaded. In fact, hardly any person is detained in a prison due to offences involving central government taxes.
} 
hand, cash budgeting exacerbates the accountability problems of already weakly institutionalised budgeting.

A standard justification for the introduction of a cash budget to curb excess fiscal deficits is that the expenditure commitment controls hitherto used have proved to be inadequate. This is true, but deficits are also caused by unrealistic revenue targets and unpredictable aid. ${ }^{6}$ Cash budget arrangements create a succession of budget crises as fund releases depend on funds actually in hand. Ambitious revenue targets combined with aid disbursements that are more volatile than revenues - especially in highly aiddependent countries (Bulir and Hamann, 2001, 30) - often exacerbate this expenditure volatility problem. ${ }^{7}$ Budgeting and planning horizons shrink to the period stipulated by the cash budget disbursements - monthly or quarterly depending on country. Under such conditions it makes little sense to even try to hold officials accountable for activities delayed or output targets not met. Planning and budgeting is still done, but have mainly symbolic meaning, as many officials openly admit (Government of Tanzania, 1998).

\section{Conclusions}

Similarities between incomes from oil and aid - in particular the fact that they do not derive from political and administrative efforts to tax domestic activities - justify the use of empirical tests of rentier state theories to explore if aid incomes have similar influences on state-society relations as oil. Ross' quantitative tests of the influence of oil incomes on political representation and accountability, using a large sample of countries, show that rentier state theories do have some general explanatory power in

\footnotetext{
${ }^{6}$ The actual effect depends on how close the budgeted expenditures are set to projected revenue and aid incomes.

${ }^{7}$ The disadvantages of cash budgeting is generally considered to be increased volatility of expenditures; a skewed composition of expenditures due to differential ministerial influence on the actual allocations of funds; and the general marginalisation of line ministries within the budget process. All three problems existed prior to cash budgeting, but tend - depending on the country in question - to be amplified by it (Stasavage and Moyo, 2000).
} 
substantiating the oil-hinders-democracy proposition. On the other hand, his tests and specifications of causal mecha nisms to support this proposition are less convincing. His identification of and arguments for such mechanisms is, however, suggestive of how the accountability effects of aid incomes could be better specified, contextualised and tested.

More context-specific case studies are therefore needed to sort out the complex and multi-directional causal relations between taxation, aid and accountability. Such studies must not just consider the income enhancing effects of aid, but also the influences of donors and aid on fiscal, taxation and expenditures policies and on the political mobilisation and demobilisation of societal groups. It is also necessary to consider how social relations of power may reinforce or neutralise taxation-aid-donor influences on state-society relations: fiscal relations are not the only influences on political bargaining processes.

Furthermore, differences between oil and aid income - in particular that aid donors are extensively involved in tax policies and administration - make it necessary to go beyond rentier state theories to understand the linkages between taxation, aid and accountability. The analyses of the effects of donor involvement in central government revenue targets on tax collection methods, taxpayer rights and budgetbased administrative accountability clearly show this.

Finally, we need an appropriate concept of accountability if we are to do further empirical research into the relationships between taxation, aid and accountability. Such a concepts needs to take into account the importance of tax administration and taxpayer rights. A good starting point is therefore Tilly's $(1997,198)$ conception of democracy as a particular type of citizenship which combines "broad and relatively equal citizenship with (a) binding consultation of citizens in regard to state personnel and policies as well as (b) protection of citizens from arbitrary state action." This "democracy" concept does not stipulate ideal outcomes or specific institutional arrangements. Moreover, a country's particular political system is characterised by various combinations of equality of citizenship - which only refers to claims on and from the state in a person's capacity as a citizen; breadth of citizenship (inclusiveness); extent of binding consultations; and protection of citizens. The 
concept is therefore analytically useful across a range of different types of statecitizen relationships, and it captures important accountability aspects of taxation in poor countries - arbitrariness and coercion - that are often overlooked.

There is still some way to go before we can answer with confidence the question posed in the title of this article. The question is important. 


\section{References}

Anena, C. and Z. Gariyo, 2001. "The rights of taxpayers vis-à-vis tax authorities in Uganda," Draft November 2000. Paper prepared for the Taxation-Aid-Democracy Research Programme.

Barbone, L., A. Das-Gupta, L. de Wulf, and A. Hansson, 1999. "Reforming tax systems: the World Bank record in the 1990s," World Bank. Policy Research Working Paper, No 2237, November 1999.

Beblawi, H. and G. Luciani, (eds.),1987. The rentier state (London: Croom Helms).

Bulir, A., and A.J. Hamann, 2001. " How volatile and unpredictable are aid flows, and what are the policy implications?" IMF Working Paper, WP/01/167.

Cooley, A., A., 2001. "Booms and busts: theorizing institutional formation and change in oil states," Review of International Political Economy, Vol 8, No.1, pp. 163-180.

Devarajan, S., A. S. Rajkumar and V. Swaroop, 1999. "What does aid to Africa finance?" The World Bank. Policy Research Working Paper Series, No 2092, 34p.

DiJohn, J., and J. Putzel, 2000. "State capacity building, taxation and resource mobilisation in historical perspective," Draft paper presented at the conference on "New institutional economics, institutional reform and poverty reduction," Development Studies Institute, London School of Economics and Political Science, 78 September, 2000.

Eriksen, S. S., 2001. "The state we're in: recent contributions to the debates on statesociety relations in Africa," Forum for Development Studies, Vol. 28, No 2., pp. 289307. 
Fjeldstad, O.H., O.Therkildsen with J. Semboja and L. Rakner, 2000. ”Taxation, aid and democracy: an agenda for research in African countries." Centre for development Research. CDR Working Papers, No 00.5.

Fjeldstad, O.H., 2001. "Taxation, coercion and donors: government tax enforcement in Tanzania. Journal of Modern African Studies, Vol. 39, no 2, pp. 289-307.

Goldsmith, A. A. 2001. "Donors, dictators, and democrats in Africa," Journal of Modern African Studies, Vol 39, No 3, pp. 411-436.

Government of Tanzania, 1998. "Public Expenditure Review. Main report." July 1998. The World Bank. Africa region.

Luoga, F., 2001. 'Taxpayers' rights and obligations: a survey of the legal situation in Tanzania," Draft, December 2001. Paper prepared for the Taxation-Aid-Democracy Research Programme.

Moore, M., 1998. "Death without taxes: democracy, state capacity and aid dependence in the fourth world," in Robinson, M. and G. White (eds.). The democratic developmental state: politics and institutional design. Oxford Studies in Democratisation. (Oxford: Oxford University Press).

Moore, M., 2001. 'Political Underdevelopment: What Causes 'Bad Governance'? Public Management Review, 3(3), 2001.

Rakner, L., 2001. "Tax policies in Tanzania in the 1990s: relations between state, interest groups and donors," (in Norwegian). Den Ny Verden, Vol. 34, No. 3, pp. 7993.

Reinikka, R., and J. Svensson, 1999. "Confronting competition: investment response and constraints in Uganda," Conference on "Assessing outcomes for a Comprehensive Development Framework,” Kampala, October 26-28, 1999. 
Ross, M. L., 1999. 'The political economy of the resource curse," World Politics, Vol 51, January 1999, pp. 297-322.

Ross, M. L., 2001. "Does oil hinder democracy?" World Politics, Vol 53, no 3, pp. 325-361.

Stasavage, D. and D. Moyo, 2000. "Are cash budgets a cure for excess fiscal deficits (and at what cost)?" World Development, Vol 28, No12, pp.2105-2122

Tanzi, V., and L. Schuknecht, 2000. Public spending in the $20^{\text {th }}$ century: a global perspective," (Cambridge: Cambridge University Press)

Therkildsen, O., 2001a. "Efficiency, accountability and implementation: public sector reform in East and Southern Africa," Democracy, Governance and Human Rights, Paper No. 3. Geneva. UNRISD.

Therkildsen, O., 2001b. "Understanding taxation in poor African countries: a critical review of selected perspectives." Forum for Development Studies, Vol. 28, No. 1, pp. 99-125.

Tilly, C, 1997. "Democracy is a lake," in Tilly, C., Roads from past to future (Lanham: Rowman \& Littlefield Publishers), pp. 193-216.

World Bank, 1999. "Project appraisal document: Tax administration project" March 11, 1999. Tanzania and Uganda Country Department. Africa Regional Office.

World Bank, 2000. Can Africa claim the $21^{\text {st }}$ century? (Washington: World Bank). 